EESTI NSV TEADUSTE AKADEEMIA TOIMETISED. XI KOIDE FOOSIKALIS-MATEMAATILISTE JA TEHNILISTE TEADUSTE SEERIA. 1962, NR. 2

ИЗВЕСТИЯ АКАДЕМИИ НАУК ЭСТОНСКОИ ССР. ТОМ .ХІ СЕРИЯ ФИЗИКО-МАТЕМАТИЧЕСКИХ И ТЕХНИЧЕСКИХ НАУК, 1962, № 2

\title{
СИНТЕЗ ГЕКСАХЛОРЦИКЛОПЕНТАДИЕНА ИЗ ПЕНТЕН-ПЕНТАНОВЫХ ФРАКЦИП СЛАНЦЕВЫХ ГАЗБЕНЗИНОВ
}

\section{Х. РАНГ}

Гексахлорциклопентадиен был синтезирован впервые Штраусом, Коллеке и Хайном ['] из циклопентадиена и гипохлорита калия. В дальнейшем было показано $[2-5,16,20]$, что он может быть синтезирован из насыщенных алифатических и циклических углеводородов $\mathrm{C}_{5}$. Они хлорируются при температуре около $100^{\circ} \mathrm{C}$ в среде образующихся продуктов реакции, которые представляют собой смесь полихлорпентанов, содержащую 6-7 атомов хлора в молекуле. Далее, смесь полихлорпентанов и хлор направляются в пустой или заполненный катализатором трубчатый реактор. Қатализатором служит инфузорная земля или другой материал с актнвной поверхностью. Процесс проводится при температуре $350-550^{\circ} \mathrm{C}$. Реакция проходит главным образом через следующие стадия: вначале полихлорпентаны превращаются в нонахлорпентен, затем октахлорпентадиен-1,3; далее, октахлорциклопентен, на базе которого образуется целевой продукт - гексахлорциклопентадиен $\left[{ }^{2}, 6,7\right]$. Гексахлорциклопентадиен может быть синтезирован также непосредственно из пентановой фракции с использованием при этом большого избытка хлора [].

Промышленное использование гексахлорциклопентадиена базируется на его реакции с диенофилами по Дильсу-Альдеру. В настоящее время при помощи этой реакции из гексахлорпентадиена пронзводятся ннсектициды: хлориндан, гептахлор, альдрин, дильдрин, эндрин, изодрин, тиодан и аллодан. Кроме того, на базе гексахлоріниклопентациена можно получить термостойкие полиэфирные $\left[{ }^{14}\right]$ и эпоксидные смолац $\left.{ }^{15}\right]$, фунгициды, стимуляторы роста растений и т. п.

Для синтеза гексахлорциклопентадиена нспользовались также пентен-пентановая фракция крекинг-бензина $\left[{ }^{6},{ }^{16}\right]$ и пиперилен $\left[{ }^{17}\right]$. В данном случае приготовленне полихлорпентанов осуществлялось периодически, хлорированием при низкой температуре с последующим повышением температуры до $100-150^{\circ} \mathrm{C}$.

В настоящей работе были изучены возможности синтеза гексахлорциклопентадиена на базе пентен-пентановых фракций сланцевых газбензинов.

Р табл. 1 и 2 приведены составы углеводородных фракций $\mathrm{C}_{5}$ сланцевых газбензинов и некоторых нефтяных крекинг-бензинов.

Выделение углеводородов $\mathrm{C}_{5}$ из сланцевых газбензинов легкө осуществимо. Соответствующие углеводороды, содержащиеся в сланцевых бензинах кипят в пределах температур $27,7-49,3^{\circ} \mathrm{C}$. При этом основная часть их выкипает прн $30-37^{\circ} \mathrm{C}$. Ввиду того, что в сланцевых бензинах низкокипящих изогексенов содержится незначительное колнчество, $\mathrm{C}_{5}$ фракция становится легко отделимой от основного компоЯента - гексена-1 (т. к. $\left.63,5^{\circ} \mathrm{C}\right)$ - следующей $\mathrm{C}_{6}$ фракции. Также легко отделяется фракция $\mathrm{C}_{5}$ от углеводородов $\mathrm{C}_{4}$, потому что сланцевые бензины не содержат таких соединений как 2,2-диметилпропан и 2-метилбутен-3. 
Таблица

\section{Индивидуальิный химический состав пентен-пентановых фракций продуктов термической переработки горючего сланца}

\begin{tabular}{|c|c|c|c|c|}
\hline Углеводороды & $\begin{array}{c}\text { Teмпература } \\
\text { кипения, } \\
{ }^{\circ} \mathrm{C}\end{array}$ & $\begin{array}{c}\text { Содержание } \\
\text { во фракции } \\
\mathrm{C}_{5} \text { бензина } \\
\text { туннельных } \\
\text { печей [9], } \\
\text { в \% }\end{array}$ & $\begin{array}{c}\text { Содержание } \\
\text { во фракции } \\
\text { C5 газбензина } \\
\text { камерніх } \\
\text { печей [ [10]. } \\
\text { в \% } \% \\
\end{array}$ & $\begin{array}{c}\text { Содержание } \\
\text { во фракцин } \\
\mathrm{C}_{5} \text { легкой } \\
\text { смолы уста- } \\
\text { новкн с } \\
\text { твердым } \\
\text { теплоноси- } \\
\text { телем ["1'], } \\
\text { в \% }\end{array}$ \\
\hline $\begin{array}{l}\text { Пентан } \\
2 \text {-метилбутан }\end{array}$ & $\begin{array}{l}36,2 \\
27,7\end{array}$ & $\begin{array}{r}30,1 \\
1,1\end{array}$ & 23,3 & $\begin{array}{r}12,1 \\
1,0\end{array}$ \\
\hline Bcero $\mathrm{C}_{5} \mathrm{H}_{12}$ & & 31,2 & 23,3 & 13,1 \\
\hline $\begin{array}{l}\text { Пентен-1 } \\
\text { Пентен-2 (транс) } \\
\text { Пентен-2 (цис) } \\
2 \text {-метилбутен-2 } \\
2 \text {-метилбутен-1 }\end{array}$ & $\begin{array}{l}29,9 \\
36,4 \\
37,1 \\
38,5 \\
31,1\end{array}$ & $\begin{array}{r}28,7 \\
15,2 \\
7,0 \\
1,9 \\
-\end{array}$ & $\begin{array}{r}15,1 \\
6,6 \\
12,0 \\
- \\
-\end{array}$ & $\begin{array}{r}18,5 \\
11,5 \\
7,4 \\
3,3 \\
5,2\end{array}$ \\
\hline Bcero $\mathrm{C}_{5} \mathrm{H}_{10}$ & & 52,8 & 33,7 & 45,8 \\
\hline $\begin{array}{l}\text { 2-метилбутадиен-1,3 } \\
\text { Пентадиен-1,3 }\end{array}$ & $\begin{array}{c}34,1 \\
42,4-42,6\end{array}$ & $\begin{array}{l}2,1 \\
3,2\end{array}$ & $\begin{array}{r}9,8 \\
19,0\end{array}$ & $\begin{array}{r}1,3 \\
22,6\end{array}$ \\
\hline Bcero диенов & & 5,3 & 28,8 & 23,9 \\
\hline $\begin{array}{l}\text { Циклопентан } \\
\text { Циклопентен }\end{array}$ & $\begin{array}{l}49,3 \\
44,0\end{array}$ & $\begin{array}{l}2,9 \\
7,8\end{array}$ & $\begin{aligned} 2,9 \\
11,3\end{aligned}$ & $\begin{array}{r}3,3 \\
13,8\end{array}$ \\
\hline Всего циклических соединений & & 10.7 & 14,2 & 17,1 \\
\hline $\begin{array}{l}\text { Bcero алифатических соеднне- } \\
\text { ний }\end{array}$ & & 89,3 & 85.8 & 82,9 \\
\hline $\begin{array}{l}\text { Изоструктур } \\
\text { Нормальных соединений } \\
\text { Всего пентанов } \\
\text { Всего пентенов }\end{array}$ & & $\begin{array}{r}5,1 \\
84,2 \\
34,1 \\
60,6\end{array}$ & $\begin{array}{r}9,8 \\
76,0 \\
25,2 \\
45,0\end{array}$ & $\begin{array}{l}10,8 \\
72,1 \\
16,4 \\
59,6\end{array}$ \\
\hline
\end{tabular}

$\mathrm{X}$ арактеристика исходного сырья. Исходным сырьем служил газ бензин туннельных печей комбината «Кивиыли». Пробы газбензина были взяты в различное время года (в январе, марте и июне). В табл. 3 приведена характеристика данных проб.

Содержание углеводородов $\mathrm{C}_{5}$ в указанных пробах газбензина определялось следуюшим образом Газбензин ректифицировался в колонке эффективностью в 60 теоретических тарелок. В полученных фракциях, выкипающих до температуры $50^{\circ} \mathrm{C}$, опреде лялись углеводороды $\mathrm{C}_{5}$ при помощи сконструированного в Институте химии АН ЭССР газо-жидкостного хроматографа * $\left.{ }^{18}\right]$. Адсорбционная колонка заполнялась диатомитовой мелочью, пропитанной в одном случае ацетонилацетоном, в другом - дибутилфталатом.

* Автор выражает благодарность Э. Арумеел за оказанную помощь. 
Индивидуальный химический состав пентен-пентановых- фракций нефтяных крекинг-бензинов

\begin{tabular}{|c|c|c|c|}
\hline Углеводороды & $\begin{array}{c}\text { Содержание во } \\
\text { фракции } \mathrm{C}_{5} \\
\text { бензина терми- } \\
\text { ческого крекин- } \\
\text { га }\left[{ }^{12}\right], \text { в \% }\end{array}$ & $\begin{array}{lr}\text { Содержание } & \text { во } \\
\text { фракции } & \mathrm{C}_{5} \\
\text { бензина катали- } \\
\text { тического } \\
\left.\text { кинга }{ }^{12}\right], \\
\text { в } \%\end{array}$ & $\begin{array}{l}\text { Содержание во } \\
\text { фракции С }{ }_{5} \\
\text { бензина терми- } \\
\text { ческого крекин- } \\
\text { га }\left[{ }^{13}\right], \text { в \% }\end{array}$ \\
\hline $\begin{array}{l}2,2 \text {-диметилпропан } \\
\text { 2-метилбутан } \\
\text { Пентан }\end{array}$ & $\begin{array}{r}0,1 \\
20,4 \\
35,2\end{array}$ & $\begin{array}{r}51,8 \\
6,7\end{array}$ & $\begin{array}{l}14,5 \\
38,2\end{array}$ \\
\hline Bcero $\mathrm{C}_{5} \mathrm{H}_{12}$ & 55,7 & 58,5 & 52,7 \\
\hline $\begin{array}{l}\text { Пентен-1 } \\
\text { Пентен-2 (транс) } \\
2 \text {-метилбутен-3 } \\
2 \text {-метилбутен-1 } \\
2 \text {-метилбутен-2 }\end{array}$ & $\begin{array}{r}12,6 \\
9,5 \\
2,4 \\
8,2 \\
6,8\end{array}$ & $\begin{array}{r}2,1 \\
9,2 \\
0,6 \\
7,6 \\
17,3\end{array}$ & $\begin{array}{r}2,2 \\
6,9 \\
5,6 \\
9,1 \\
14,2\end{array}$ \\
\hline Bcero $\mathrm{C}_{5} \mathrm{H}_{10}$ & 39,5 & 36,8 & 38,0 \\
\hline $\begin{array}{l}\text { Циклопентан } \\
\text { Циклопентен }\end{array}$ & $\begin{array}{l}2,4 \\
2,4\end{array}$ & $\begin{array}{l}0,9 \\
1,8\end{array}$ & $\begin{array}{l}6,4 \\
2,9\end{array}$ \\
\hline Всего циклических соединений & 4,8 & 2,7 & 9,3 \\
\hline $\begin{array}{l}\text { Всего алифатических соединений } \\
\text { В том числе: } \\
\text { а) изоструктур } \\
\text { б) нормальных структур }\end{array}$ & $\begin{array}{l}37,9 \\
57,3\end{array}$ & $\begin{array}{l}77,3 \\
18,0\end{array}$ & $\begin{array}{l}90,7 \\
. \\
43,4 \\
47,3\end{array}$ \\
\hline $\begin{array}{l}\text { Bcero пентанов } \\
\text { Bcero пентенов }\end{array}$ & $\begin{array}{l}58,1 \\
41,9\end{array}$ & $\begin{array}{l}59,4 \\
38,6\end{array}$ & $\begin{array}{l}59,1 \\
40,9\end{array}$ \\
\hline
\end{tabular}

Для синтеза гексахлорциклопентадиена использовались две фракции газбензина туннельных печей: $30-36^{\circ} \mathrm{C}$ и $36-46^{\circ} \mathrm{C}$.

В табл. 4 представлен состав указанных фракций.

Кроме того, в качестве исходного сырья для синтеза использовалась фракщия

Таблица 3

Характеристика газбензина туннельных печей в зависимости от времени года

\begin{tabular}{|c|c|c|c|}
\hline Показатели & $\begin{array}{c}\text { Проба взята } \\
\text { в январе }\end{array}$ & $\begin{array}{c}\text { Проба взята } \\
\text { в марте }\end{array}$ & $\begin{array}{l}\text { Проба взята } \\
\text { в июне }\end{array}$ \\
\hline $\begin{array}{l}\text { Удельный вес } d_{4}^{20} \\
\text { Показатель преломления } n_{\mathrm{D}}^{20} \\
\text { Фракционный состав: } \\
\text { начало кипения, }{ }^{\circ} \mathrm{C} \\
10 \% \text { выкипает, }{ }^{\circ} \mathrm{C} \\
50 \% \\
80 \% \\
90 \%\end{array}$ & $\begin{array}{l}0,7189 \\
1,4095 \\
24 \\
36 \\
71 \\
186 \\
232 \\
22,0\end{array}$ & $\begin{array}{r}0,7246 \\
1,4132 \\
28 \\
38 \\
76 \\
220\end{array}$ & $\begin{array}{l}0,7289 \\
1,4145 \\
28 \\
38 \\
78 \\
225 \\
18,4\end{array}$ \\
\hline
\end{tabular}


$30-36^{\circ} \mathrm{C}$, полученная путем простой перегонки газбензина. Эта фракция имела следующие показатели: $n_{\mathrm{D}}^{20}-1,3752 ; d_{4}^{20}-0,6448$; бромное число $\left[{ }^{19}\right]-125$; содержание углеводородов $\mathrm{C}_{5}-67 \%$. Полученная фракция содержала циклопентадиен (определено качественно при помощи спектрометра).

Также применялась фракция $30-44^{\circ} \mathrm{C}$, полученная ректификацией газбензина камерных печей в колонке эффективностью в 60 теоретических тарелок.

Для выяснения влияния сернокислотной рафинации на состав углеводородов $\mathrm{C}_{5}$ и изменения их содержания в газбензине была проведена рафинация последнего концентрированной серной кислотой. В результате проведенного процесса рафинации содержание углеводородов $C_{5}$ в газбензине уменьшалось с 22,0 до 19,8\%. Изменение состава углеводородов лучше всего характеризуется содержанием пиперилена в сомтветствующей фракции, кипящей в пределах температур $36-46^{\circ} \mathrm{C}$, определенного при помощи газо-жидкостной хроматографии. Результаты анализа представлены в табл, 4.

Таблица 4

\section{Индивидуальный химический состав сырья для синтеза гексахлорциклопентадиена}

\begin{tabular}{|c|c|c|c|}
\hline Углеводороды & $\begin{array}{c}\text { Фракция } 30-36^{\circ} \mathrm{C} \\
\text { газбензина, рафи- } \\
\text { нированного сер- } \\
\text { ной кислотой }\end{array}$ & $\begin{array}{l}\text { Фракция } \\
36-46^{\circ} \mathrm{C}\end{array}$ & $\begin{array}{c}\text { Фракция } 36-46^{\circ} \mathrm{C} \\
\text { газбензина, рафи- } \\
\text { нированного сер- } \\
\text { ной кислотой }\end{array}$ \\
\hline $\left.\begin{array}{l}\text { 2-метилбутан } \\
\text { Пентан } \\
\text { Пентен-1 } \\
\text { Пентен-2 (транс) } \\
\text { Пентен-2 (цис) } \\
2 \text {-метилбутен-2 } \\
\text { Пентадиен-1,3 } \\
\text { Циклопентен } \\
\text { Циклопентан }\end{array}\right\}$ & $\begin{array}{r}0,5 \\
34,4 \\
29,7 \\
18,6 \\
11,3 \\
3,7 \\
1,4 \\
0,4\end{array}$ & $\begin{array}{r}\overline{17,1} \\
\overline{15,8} \\
13,1 \\
8,4 \\
17,0 \\
28,6\end{array}$ & $\begin{array}{r}\overline{24,8} \\
\overline{15,0} \\
11,3 \\
7,7 \\
12,0 \\
29,1\end{array}$ \\
\hline
\end{tabular}

Из табл 4 видно, что даже в рафинированном бензине содержится сравнительно большое количество пиперилена, которое в пересчете на суммарный бензин (фракция до $200^{\circ} \mathrm{C}$ ) составляет $0,2 \%$.

Получение полихлорпентанов. На основе вышеохарактеризованных пентен-пентановых фракций были получены полихлорпентаны при помощи фотохимического хлорирования, осуществленного в представленной на фиг. 1 колонке. Колонка состояла из двух секций, в каждой из которых имелась спираль для теплообена. Приготовление полихлорпентанов из всех видов сырья проводилось периодически. Колонка заполнялась углеводородами $\mathrm{C}_{5}$. Смесь хлорировалась при температуре ниже $15^{\circ} \mathrm{C}$ до полного насыщения двойных связей (бромное число равнялось нулю). В дальнейшем для иницийрования процесса хлорирования применялось ультрафиолетовое облучение. Средняя температура процесса при этом составляла около $80-100^{\circ} \mathrm{C}$. Кроме того, хлорировалась периодически смесь пентенов (95,5\% пентен-1, 4,5\% пентен-2), полученных при дегидратации пентанола-1 на окнси алюминия при $380^{\circ} \mathrm{C}$, и смесь метилбутенов, полученных при дегидратации изоамилового спирта на окиси алюминия при $420-450^{\circ} \mathrm{C}$. Характеристика полученных продуктов приведена в табл. 5 .

Как показал анализ и органолептическая оценка (цвет), полихлорпентаны, полученные из диенсодержащего сырья (в особенности циклопентадиена), содержат полимеры и продукты окислення. Эти нежелательные побочные продукты удалось устранить проведением непрерывного процесса хлорирования. 


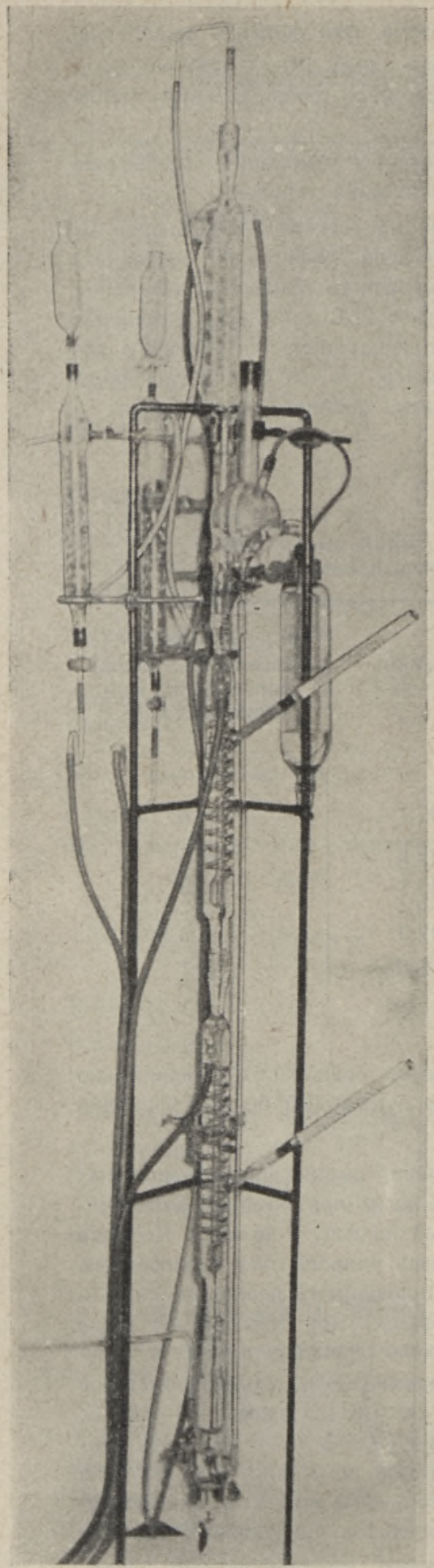

Фиг. 1. Хлоратор
Из всех соответствующих фракций сланцевых газбензинов (за исключением содержащих циклопентадиен) при непрерывном хлорировании в среде полихлорпентанов (полученных на базе фракции $30-36^{\circ} \mathrm{C}$ серной кислотой рафинированного газбензина туннельных печей) при температуре $80-100^{\circ} \mathrm{C}$ и ультрафнолетовом облученин удалось получить бесцветные полихлорпентаны, не содержащие полимеров и продуктов окисления.

Разработанная методика проверялась на хлорировании пиперилена. Для этого пары пиперилена $\left(n_{\mathrm{D}}^{20}-1,4328, d_{4}^{20}-0,6845\right)$ непрерывно подавались сквозь пористую пластинку в колонку, заполненную 630 г полихлорпентана $\left(n_{\mathrm{D}}^{20}-1,5362\right.$, $\left.d_{4}^{20}-1,6500\right)$. Одновременно туда же подавался хлор в соотношении $\mathrm{Cl}_{2}: \mathrm{C}_{5} \mathrm{Cl}_{8}=4: 1$. Верхняя часть колонки облучалась ультрафиолетовыми лучами. Температура смеси поддерживалась в пределах $80-100^{\circ} \mathrm{C}$. В итоге было получено 958 r полихлорпентанов, свойства которых оказались весьма близкими к свойствам первоначально загруженных полихлорпентанов.

Синтез гексахлорциклопента д и ен а. В дальнейшем был изучен синтез гексахлорциклопентадиена на базе полученных полихлорпентанов (см. табл. 5), Процесс осуществлялея в трубчатом реакторе при двух зонах нагрева. Диаметр трубки, заполненной катализатором, составлял 20 мм, длина контактной зоны 850 мм $(620+230)$. В трубку подавались одновременно полихлорпентаны и хлор. Нагрузка ка-

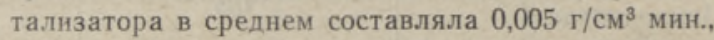
избыток хлора $20 \%$ от теоретического. Сконденсированный катализат освобождался от хлора и хлористоводородного газа путем продувания воздухом и последующим промыванием водой. Высушенный катализат подвергался ректификацин.

Было изучено влияние природы катализатора, температуры, качества и соотношения ингредиентов на выход гексахлорциклопентадиена.

В качестве катализатора служил силикагель марки КСМ, с размером зерен 2-3 мм.

Кроме того, применялся силикаге́ль, пропитанный хлоридами железа, меди, никеля и кобальта, а также силикагель с сажденными на него гидроокисями железа и кобальта, которые последующим хлорированием переводились в хлориды. Выяснилось, что эффективность пропитанного катализатора существенно не увеличивается, а активность катализаторов, обработанных методом осаждения, заметно уменьшалась из-за уменьшения активной поверхности катализатора.

Результаты опытов представлены в сводной табл. 6. Как показали данные повторной ректифн- 
Таблица 5

Характеристика полихлорпентанов

Полихлорпентаны

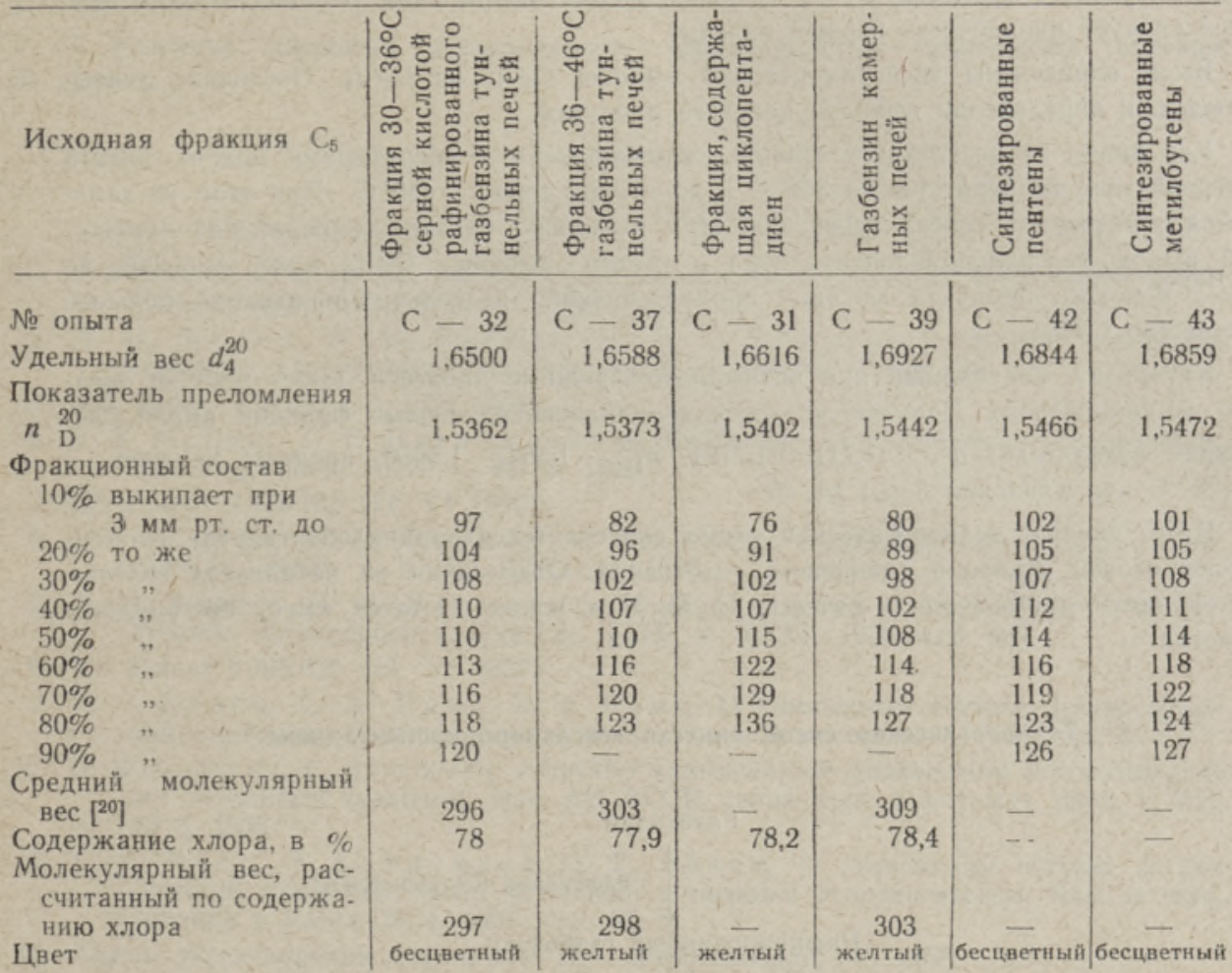

кации, приведенные в табл. 6, головка состояла в основном из гексахлорбутадиена и некоторого количества четыреххлористого углерода, тетрахлорэтилена и гексахлорэтана. Фракция $\mathrm{C}_{5} \mathrm{Cl}_{8}$ (отделялась при помощи кристаллизации) состояла из октахлор-

Таблица 6

Результаты синтеза гексахлорциклопентадиена

\begin{tabular}{|c|c|c|c|c|c|c|c|c|c|}
\hline \multirow[b]{2}{*}{$\begin{array}{c}\text { 은 } \\
\text { опыта }\end{array}$} & \multirow[b]{2}{*}{ 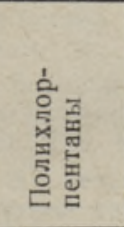 } & \multirow{2}{*}{ 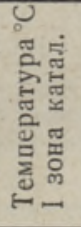 } & \multirow{2}{*}{ 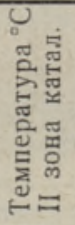 } & \multirow[b]{2}{*}{$\begin{array}{c}\text { Цвет катали- } \\
\text { зата }\end{array}$} & \multicolumn{5}{|c|}{ Фракционный состав катализата } \\
\hline & & & & & 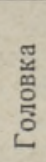 & نే & $\dot{u}^{\infty}$ & 迆 & 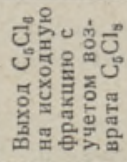 \\
\hline $\begin{array}{l}\mathrm{T}-20 \\
\mathrm{~T}=21 \\
\mathrm{~T}-24 \\
\mathrm{~T}-25 \\
\mathrm{~T}=28 \\
\mathrm{~T}=29 \\
\mathrm{~T}=43 \\
\mathrm{~T}=41^{*} \\
\mathrm{~T}=48\end{array}$ & $\begin{array}{l}\mathrm{C}=32 \\
\mathrm{C}=32 \\
\mathrm{C}=32 \\
\mathrm{C}=32 \\
\mathrm{C}=32 \\
\mathrm{C}=32 \\
\mathrm{C}=37 \\
\mathrm{C}=31 \\
\mathrm{C}=39\end{array}$ & $\begin{array}{l}380 \\
350 \\
300 \\
420 \\
450 \\
370 \\
380 \\
380 \\
380\end{array}$ & $\begin{array}{l}450 \\
430 \\
400 \\
500 \\
530 \\
440 \\
450 \\
450 \\
450\end{array}$ & $\begin{array}{l}\text { желтый } \\
\text { " } \\
\text { коричневый } \\
\text { ӧ } \\
\text { оранжевый } \\
\text { коричневый } \\
\text { " }\end{array}$ & $\begin{array}{r}19 \\
28 \\
10 \\
9 \\
14 \\
8\end{array}$ & $\begin{array}{l}60 \\
50 \\
28 \\
56 \\
58 \\
54 \\
65 \\
46 \\
57\end{array}$ & $\begin{array}{r}22 \\
28 \\
30 \\
8 \\
-30 \\
20 \\
15 \\
16\end{array}$ & $\begin{array}{r}17 \\
14 \\
6 \\
6 \\
25 \\
19\end{array}$ & $\begin{array}{l}68,6 \\
65,5 \\
44 \\
49,5 \\
45,5 \\
68,5 \\
72,8 \\
51,4 \\
62\end{array}$ \\
\hline
\end{tabular}

* Все данные перечислены на содержание углеводородов $\mathrm{C}_{5}(67 \%)$ во фракции. 
циклогентена и октахлорпентадиена. Фракция $\mathrm{C}_{5} \mathrm{Cl}_{8}$ обычно рассматривалась как потенциальный гексахлорциклопентадиен. Последний можно синтезировать путем добавления фракции $\mathrm{C}_{5} \mathrm{Cl}_{8}$ к смеси полихлорпентанов [ซ], нли в результате проведения самостоятельного процесса $\left[{ }^{21},{ }^{22}\right]$. С точки зрения оформления технологического процесса следует предпочесть первый вариант.

Были определены экспериментально выходы $\mathrm{C}_{5} \mathrm{Cl}_{6}$ из $\mathrm{C}_{5} \mathrm{Cl}_{8}$. Последние учитывались при определении выходов целевого продукта.

Қак видно из результатов опытов, оптимальными температурами можно считать в первой зоне температуры до $380^{\circ} \mathrm{C}$ и во второй зоне $-450^{\circ} \mathrm{C}$. При этом не замечается образование гексахлорбензола. При несколько низших температурах суммарный выход гексахлорциклопентадиена с учетом возврата $\mathrm{C}_{5} \mathrm{Cl}_{8}$ тоже высокий, но выход целевого продукта за один проход низкий, поскольку лобразуется большое количество $\mathrm{C}_{5} \mathrm{Cl}_{8}$.

Катализат, получаемый при оптимальном режиме процесса, имеет цвет от желтого до оранжевого. Полученные, гексахлорциклопентадиеновые фракции имели следующие показатели: $d_{4}^{20}-1,7110-1,7121, n_{\mathrm{D}}^{20}-1,5647-1,5650$, пределы кипения $80-85^{\circ}$ С при давлении 3 мм рт. ст.

Ниже следует технологическая схема синтеза гексахлорциклопентадиена из пентен-пентановых фракций сланцевого газбензина. Отделенная из катализата головка может найти применение в качестве фумиганта почвы. Остаток имеет пестицидные свойства.

\section{Технологическая схема синтеза гексахлорциклопентадиена}

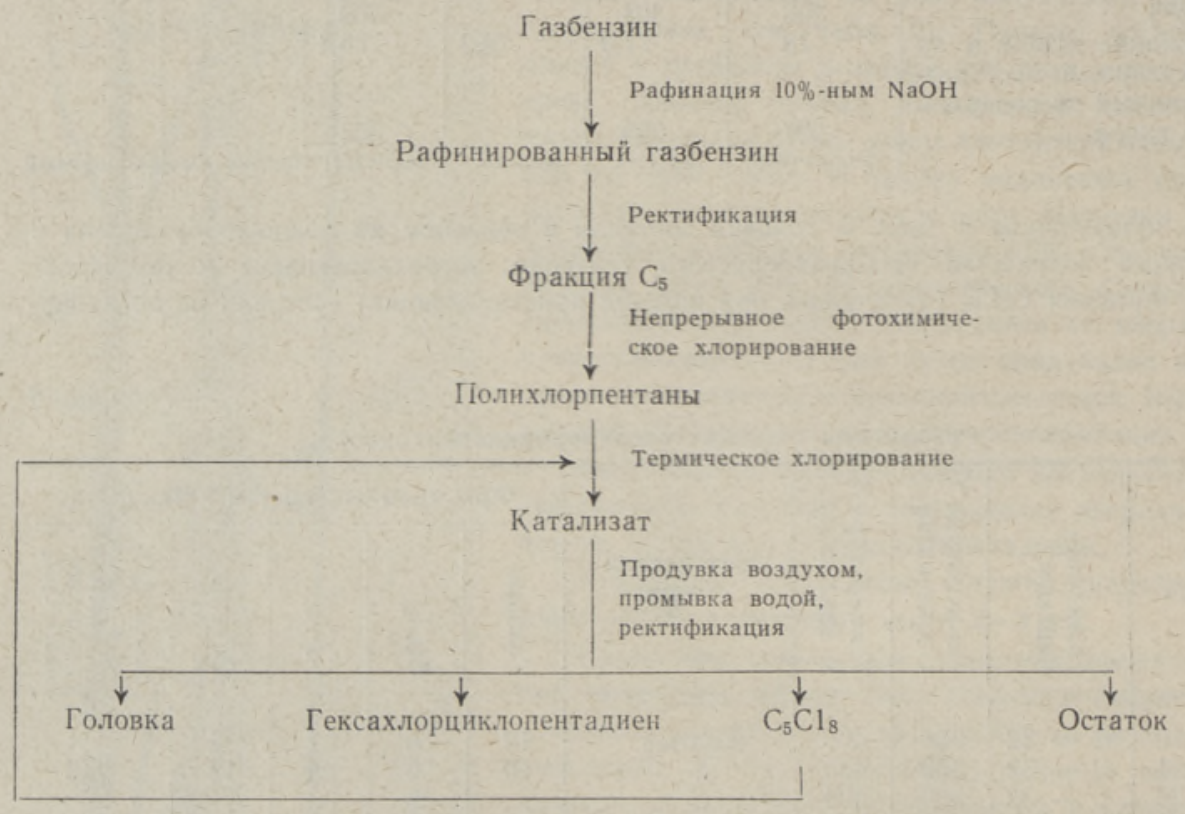

\section{Выводы}

1. Выделение фракции $\mathrm{C}_{5}$ из сланцевых газбензинов легко осушествимо, так как основные компоненты этой фракции кипят в узких пределах температур (для газбензина туннельных печей - $30-37^{\circ} \mathrm{C}$, для газбензнна камерных печей $\left.-30-44^{\circ} \mathrm{C}\right)$. 
2 При непрерывном хлорировании фракции $\mathrm{C}_{5}$ сланцевых газбензинов могут быть получены полихлорпентаны, пригодные для синтеза гексахлорциклопентадиена, и что при периодическом проведении процесса происходят значительная полимеризация и окисление продуктов реакции за счет присутствующих диеновых углеводородов.

3. Удаление диеновых углеводородов сернокислотной рафинацией бензина не удается.

\section{ЛИТЕРАТ У Р А}

1. F. Stra us, L. K ollek, W. Heyn, Ober den Ersatz positiven Wasserstoffs durch Halogen. Ber, 1930, 63 B, S. $1868-1885$.

2. Л. М. Коган, Н. М. Бурмакин, Н. В. Черняк, О химизме процессов глубокого хлорирования пентана, ЖОХ, т. XXVIII, 1958, стр. 27.

3. Brit. Patent 735025 (10. VIII 1955).

4. E. T. McBee, C. F. B a r a n a uskas, Production of Hexachlorocyclopentadiene. Ind. Eng. Chem. 1954, v. 46, p. 1628.

5. US Patent 2473162 (14. VI 1949).

6. Л. Н. Коган, Н. М. Бур м а ин,. Об основах технологии гексахлорциклопентадиена, ЖПХ, т. XXXI, 1958, стр. 1585.

7. Л. Н. Коган, Н. М. Бурмакин, Н. П. Игнатова, Н. В. Черняк, Получение октахлорпентадиена-1.3, ЖПХ, т. ХХХІ, 1958, стр. 507.

8. US Patent 2795622 (11. VI 1957).

9. О. Г. Э йз ен, С. А. Р ан г, Х. А. Р ан г, О химическом составе легких фракций сланцевого бензина, Хим. и техн. топлив и масел, № 3, 1960, стр. 8.

10. G. Klesment, E. A r u me e l, Pōlevkivi kamberahjude gaasbensiini mittearomaatse osa keemilisest koostisest. Изв. АН ЭССР, серия техн. и физ.-мат. наук, т. VII, № 3, 1958.

11. С. А. Р анг, Э. Х. А румеел, О. Г. Эйзен, О химическом составе легких фракций сланцевой смолы установки с твердым теплоносителем, Хим. и техн. топлива и масел, № 4, 196i, стр. 40.

12. Химия углеводородов нефии, том II, Гостоптехиздат, Л., 1958.

13. А. В. Топчиев, И. А. Мусаев, Э. Х. Исхакова, А. Н. Кислин ский, Г. Д. Г альперн, О химическом составе бензина термического крекинга, Хим. и техн, топлива, № 12,1956 , стр. 1.

14. P. Robitschek, T. S. B e a n, Flame-Resistant Polyesfers from Hexachlorocyclopentadiene. Ind. Eng. Chem: 1954, No. 46, p. 1628.

15. P. Robitschek, S. J. Nelson, Flame and Heat-Resistant Epoxy Resins. Ind. Eng. Chem. 1956, v. 48, p. 1951.

16. П. Г. Вольфсон, С. Д. Володкович, Н. Н. Мельников, А. В. Молч а нов, Ю. Н. С а пожков, Хлорсодержащие инсектициды-хлориндан и гептахлор, Сб. НИУИФ, вып. 158, Органические инсектофунгициды и гербициды, М., 1958.

17. С. Д. Володкович, С. С. Кукаленко, Н. Н. Мельников, Получение гексахлорциклопентаднена из некоторых полихлоруглеводородов, Сб. НИУИФ, вып. 158, Инсектофунгициды и гербициды, М., 1958.

18. О. Г. Эйзен, Э.Х. А р умеел, В. Иоонсон, Применение метода газо-жидкосгной хроматографии для определения химического состава легких продуктов термического разложения горючего сланца, Изв. АН ЭССР, сер. физ.-мат. и техн. наук, т. IX, № 2, 1960, стр. 113.

19. H. D. D u B o is, D. A. S koog, Determination of Bromine Addition Numbers, Anal, Chem., 1948, v. 20, p. 624 .

20 В. Я. Михкельсон, Криоскопический метод определения молекулярных ве$\cos$ с применением термометров сопротивления. Журн. анал. химии, IX, № 1, 1954.

21. Brit. Patent 703202 (27. I 1954).

22. US Patent 2742506 (17. IV 1956). 


\section{HEKSAKLOORTSUKLOPENTADIEENI SUNTEES POLLEVKIVI GAASBENSIINIDE PENTEENI-PENTAANI FRAKTSIOONIST}

\section{H. Rang}

\section{Resümee}

Heksakloortsüklopentadieen on lähtematerjaliks mitmete insektitsiidide, kuumuskindlate vaikude, fungitsiidide, taimekasvu regulaatorite jm. valmistamisel. Heksakloortsüklopentadieeni sünteesitakse tänapäeval tööstuslikult pentaanifraktsioonist, ja nimelt viimase kloreerimisel saadavatest polükloorpentaanidest. Kasutades heksakloortsüklopentadieeni sünteesimiseks penteeni-pentaani fraktsioone, saab polükloorpentaanide valmistamisel vähendada kloori kulu.

Käesolevas töös on uuritud heksakioortsüklopentadieeni sünteesimise vōimalusi pōlevkivi gaasbensiinide $\mathrm{C}_{5}$-fraktsioonist. Nagu nähtub pōlevkivi gaasbensiinide individuaalsest koostisest, pole $\mathrm{C}_{5}$-fraktsiooni eraldamine neist keerukas.

Heksakloortsüklopentadieeni sünteesiti nii tunnelahjiı kui ka kamberahju gaasbensiinide rektifikatsioonil saadud $\mathrm{C}_{5}$-fraktsioonist. Esmalt sünteesiti neist vertikaalses kolonnis polükloorpentaanide segud. Näidati, et pōlevkivi gaasbensiini $\mathrm{C}_{5}$-fraktsiooni kloreerimisel võib saada polükloorpentaane, mis sobivad heksakioortsüklopentadieeni sünteesimiseks. Dieene sisaldavast $\mathrm{C}_{5}$-fraktsioonist perioodilisel protsessil sünteesitud polükloorpentaanid sisaldavad polümerisatsiooni- ja oksüdatsiooniprodukte. Leiti, et väävelhappega rafineerides ei ônnestunud dieene $\mathrm{C}_{5}$-fraktsioonist eraldada.

Töötati välja üheastmeline pidev protsess suure olefiinsete ja dieensete süsivesinike sisaldusega $\mathrm{C}_{5}$-iraktsiooni polükloreerimiseks. Polükloorpentaanide saagis oli suur ja nad ei sisaldanud polümerisatsiooni- ega oksüdatsiooniprodukte.

Edasi uuriti katalüsaatori, polükloorpentaanide kvaliteedi ja temperatuuri mổju heksakloortsüklopentadieeni saagisele ja selgitati välja heksakloortsüklopentadiceni sünteesimise optimaalsę̧ tingimused pōlevkivi gaasbensiini $\mathrm{C}_{5}$-fraktsioonist.

\section{Eesti NSV Teaduste Akadeemia Keemia Instituut}

Saabus toimetusse 20. VI 1961

\section{PREPARATION OF HEXACHLOROCYCLOPENTADIENE FROM PENTENE-PENTANE FRACTION OF SHALE OIL}

\section{H. Rang}

\section{Summary}

Hexachlorocyclopentadiene is a raw material for many insecticides, head-resistent resins, fungicides, plant growth stimulators, etc.

This paper is a report of an investigation into possibilities of preparing hexachlorocyclopentadiene from $\mathrm{C}_{5}$ iractions of shale oil. The main compounds of these fractions are normal pentenes, pentane, cyclopentene and piperylene. It is not difficult to isolate the $\mathrm{C}_{5}$ iraction from shale oil by rectification. At first polychloropentanes were prepared from the $\mathrm{C}_{5}$ fraction of shale oil. If polychloropentanes are prepared periodically, they contain polymers and oxydation products, which are formed irom dienes. It is not expedient to remove the dienes of the $\mathrm{C}_{5}$ fraction by purifying shale-oil gasoline with sulphuric acid. In this paper it is shown that in an one-stage continuous process it is possible to prepare, from the $\mathrm{C}_{5}$ fraction of shale oil, pure polychloropentanes, which are colourless liquids. It is possible to chlorinate the piperylene, too, without any oxydation or polymerization in a continuous one-stage process.

For preparing hexachlorocyclopentadiene, the polychloropentanes were subjected to thermal chlorination. The mixture of chlorine and polychloropentanes was passed through a tube reactor which was filled with silica-gel.

The $\mathrm{C}_{5}$ fractions of shale oil gave hexachlorocyclopentadiene as a product, in yields as high as $65-70 \%$. 